\title{
Kemampuan Representasi Simbolik Matematik Siswa SMP Menggunakan Blended Learning
}

\author{
Elsa Komala ${ }^{1, *}$, Sarmini $^{2}$ \\ ${ }^{1}$ Universitas Suryakancana \\ ${ }^{2}$ SMP Negeri 3 Cianjur \\ *elsakomala@gmail.com
}

\begin{tabular}{|l|l|l|l|}
\hline Received : 29-09-2020 & Revised: $30-10-2020$ & Accepted: $10-11-2020$ & Published: $05-12-2020$ \\
\hline
\end{tabular}

\begin{abstract}
ABSTRAK
Tujuan artikel ini membahas tentang kemampuan representasi simbolik matematik siswa dalam menyelesaikan soal, dan melihat respon siswa pada pembelajaran matematika menggunakan blended learning. Penelitian ini menggunakan penelitian deskriptif kuantitatif, dengan memberikan enam soal kemampuan representasi simbolik matematik terhadap 30 siswa kelas IX-6 di SMP Negeri 3 Cianjur tahun ajaran 2019/2020. Data dalam penelitian ini berupa soal tes kemampuan representasi simbolik matematik dan angket. Hasil angket dihitung berdasarkan persentase respon terbesar yang kemudian dideskripskan dengan kata-kata. Hasil yang diperoleh bahwa kemampuan representasi simbolik matematik dengan menggunakan blended learning rata-ratanya 75 , artinya lebih dari $80 \%$ siswa yang menggunakan blended learning hasil pembelajarannya tuntas. Respon siswa pada pembelajaran matematika menggunakan blended learning sebagian besar memberikan respon positif.
\end{abstract}

Kata Kunci : Kemampuan Representasi Simbolik Matematik, Blended Learning.

\section{ABSTRACT}

The purpose of this article describe the ability of mathematical symbolic representation of students in solving problems and determine students' responses to learning mathematics using blended learning. This research uses quantitative descriptive research, by giving six questions about the symbolic mathematical representation ability of 30 students of class IX-6 in Junior High School 3 Cianjur in the academic year 2019 / 2020. The data in this study are a matter of mathematical symbolic ability and mathematical representation. The questionnaire is obtained based on the results of the largest percentage of answers which are then translated into words. Based on the results of the study, the ability of mathematical symbolic representation using blended learning averages 75 , meaning that more than $80 \%$ of students who use blended learning have complete learning outcomes. Students' responses to mathematics learning using blended learning most of the gave positive responses.

Keywords: Mathematical Symbolic Representation, Blended Learning.

\section{PENDAHULUAN}

Dampak terbesar dari perubahan zaman salah satunya berasal dari berkembangnya teknologi yang berasal dari kemampuan SDM yang memanipulasi pengetahuan menjadi sesuatu yang dapat bermanfaat untuk peradaban dunia. Perkembangan teknologi yang pemanfaatnnya sangat banyak ini hendaknya dimanfaatkan secara optimal salah satunya yakni untuk perkembangan pendidikan dan meningkatkan kualitas pembelajran di sekolah 
(Sanusi, Septian, \& Inayah, 2020; Tsany, Septian, \& Komala, 2020). Menurut Kusairi (Husamah, 2014: 37), perkembangan ICT yang manfaatnya sangat banyak ini pemanfaatkannya belum secara optimal dalam kegiatan pembelajaran. Dengan demikian upaya dalam pengintegrasian ICT dalam kegiatan pembelajaran kurang memiliki dampak yang nyata.

Dalam pembelajaran matematika di sekolah, pengintegrasian ICT perlu dilaksanakan dalam menunjang kegiatan belajar mengajar untuk menumbuhkan motivasi siswa supaya dapat menarik siswa sehingga tidak menjadi bosan (Septian, Darhim, \& Prabawanto, 2020). Sarana pembelajaran yang mendukug dan berkembang baik yang ada di sekolah ataupun yang dimiliki siswa secara pribadi, memungkinkan para siswa bisa belajar dengan memanfaatkan perkembangan teknologi dan mengikuti alur pearkembangan zaman. Matematika salah satu yang berperan penting dalam berbagai disiplin ilmu sehingga dapat memajukan daya pikir manusia, sehingga dalam pembelajaran matematika diharapkan tidak hanya mencapai ranah kognitif saja akan tetapi ranah afektif dan ranah psikomotorik (Maskur et al., 2020; Ari Septian, Suwarman, Monariska, \& Sugiarni, 2020). Dalam kurikulum 2013 guru tidak dijadikan sebagai pusat suatu pembelajaran, melainkan sebagai fasilitator yang memanfaatkan dan memaksimalkan teknologi yang sedang berkembang sehingga diharapkan mampu merencanakan kegiatan belajar yang efektif, inovatif dan kondusif, sehingga tujuan pembelajaran dapat tercapai yaitu menghasilkan siswa yang cerdas, berdaya nalar tinggi, serta berkararakter seperti berkepribadian yang baik dan mandiri.

Lima standar kompetensi menurut NCTM (2000), kemampuan representasi matematika merupakan sala satu yang harus dimiliki siswa. Kemampuan representasi juga dalam standar proses pembelajaran matematika sangat penting, karena dengan kemampuan representasi yang tinggi diharapkan dalam menyelesaikan suatu permasalah yang disajikan oleh guru, selain itu siswa juga dapat dikatakan memiliki kemampuan pemecahan masalah, penalaran, koneksi, dan komunikasi yang baik, yang tentunya akan menghasilkan pembelajaran yang lebih bermakna. Masalah yang diberikan dan disajikan guru pada saaat pembelajaraan dapat diselesaikan siswa menggunakan berbagai representasi, misalnya menggunakan visual, myatakannya dengan pemodelan matematika atau persamaan, dan dengan menggunakan representasi verbal dalm bentuk tertulis. Bruner dalam (Tall, 1996) mengatakan bahwa representasi tumbuh bersama dalam diri siswa, ia juga membedakan representasi menjadi tiga yaitu enaktik, ikonik, dan simbolis, di mana representasi enaktik merupakan representasi yang menggunakan tindakan; representasi ikonik menggunakan 
gambar/pola-pola; dan yang terakhir adalah representasi simbolis dilakukan menggunakan bahasa matematika dan symbol. Villegas (2009) membagi representasi menjadi tiga bentuk yaitu representasi verbal, representasi gambar, dan representasi simbolik.

Pada siswa SMP berdasarkan pengalaman guru matematika sebagai pengajar di kelas secara langsung, masih tedapat siswa yang kesulitan dalam merepresentasikan ideide matematik dalam membuat persamaan (simbolik) atau model matematis dalam menentukan penyelesaian dari permasalahan matemaika yang diberikan, sehingga siswa akan terhambat dan kurang optimal dalam menyelesaikannya. Berdasarkan fakta di kelas, kesulitan yang dialami siswa itu kemungkinan karena kemampuan awal yang dimiliki siswa sebelumnya tidak maksimal. Keberagaman jawaban siswa dalam menjawab soal representasi dipengaruhi oleh kemampuan awal matematikanya dan merupakan wujud dari strategi penyelesaian siswa dalam menyelesaikan soal tes kemamapuan representasi yakni kemamapuan visual, ekspresi matematik dan kata-kata yang diberikan berdasarkan kebiasaan berpikir masing-masing siswa (Komala dan Suryadi, 2018). Fakta lain berdasarkan pengalaman guru yaitu siswa tidak terbiasa dengan soal yang harus membuat persamaan atau pemodelan matematika (simbolik), kemungkinan yang lain adalah siswa tidak bisa merepresentasikan soal cerita kebentuk simbol. Sejalan dengan Komala, dkk (2020), kesalahan siswa terjadi karena tidak biasa membaca soal yang panjang, siswa biasanya diberi soal yang langsung kepada inti masalah yang mengakibatkan siswa malas untuk membaca suatu soal yang harus dicari dulu maksud dari soal tersebut. Selain itu hambatan epistimologis pada kemampuan representasi yang muncul adalah terkait kemampuan siswa memahami maksud suatu soal dan merepresentasikannya menjadi suatu notasi atau penyimbolan yang lebih sederhana dan model matematis (Komala, dkk: 2020).

Kemampuan representasi secara luas digunakan dalam kajian matematika karena representasi dapat membantu guru dan siswa untuk mengembangkan, berbagi, dan menyajikan situasi masalah nyata kedalam bahasa matematis. Untuk itu diperlukan pembelajaran yang bisa mengakomodir kemampuan representasi siswa dengan memanfaatkan serta memaksimalakan teknologi yang ada di lingkungan sekolah. Salah satu model pembelajaran yang berbasis teknologi dengan memanfaatkan dan memaksimalkan perkembangan teknologi yang sedang berkembang saat ini blended learning diaanggap sebagai salah satu alternatif pembelajaran yang dapat di gunakan.

Menurut (Kusairi dalam Husamah, 2014; Seidl, 2005) mengungkapkan bahwa ada banyak kelebihan dari blended learning jika dibandingkan dengan pembelajaran lainnya, misalnya pembelajaran tatap muka, e-learning (baik online, offline), serta m-learning, 
kelebihan blended learning tersebut diantaranya: (1) Siswa leluasa dapat mempelajari materi secara mandiri dengan memanfaatkan materi-materi yang tersedia secara online; (2) Siswa bisa melakukan diskusi dengan guru atau siswa yang lain di luar jam tatap muka; (3) Aktifitas pembelajaran siswa yang dilakukan di luar jam tatap muka dapat dikelola serta pantau oleh guru dengan baik; (4) Guru dapat menambahkan materi pengayaan melalui fasilitas internet; (5) Guru dapat meminta siswa mempelajari materi atau mengerjakan tes yang dilakukan sebelum pembelajaran; (6) Guru dapat menyelenggarkan kuis, memberikan balikan, dan mengunakan hasil tes dengan efektif; (7) Antar siswa bisa saling bertukar file.

Berdasarkan permasalahan yang telah dijelasakan sebelumnya, rasanya penting untuk melihat kemampuan representasi simbolik matematik siswa dengan menggunakan blended learning, serta melihat respon siswa pada pembelajaran matematika menggunakan blended learning.

\section{Kemampuan Representasi Simbolik}

Salah satu dari tiga jenis representasi adalah representasi simbolik, menurut Villegas (2009) yaitu representasi yang dapat membuat suatu bilangan, operasi dan tanda penghubung, simbol aljabar, operasi matematika dan relasi, angka, dan berbagai jenis lain. Sehingga indikator dalam kemamapuan representasi simbolik disini beradsarkan Villegas (2009), yakni siswa dapat menyajikan dan menyelesaikan suatu permasalah dalam bentuk model matematis berupa operasi aljabar (model ekspresi matematis).

\section{Blended Learning}

Garrison \& Vaughan (2008: 5) menyatakan bahwa Blended learning merupakan model pembelajaran yang mengkombinasikan antara pembelajaran tatap muka dan pembelajaran online. Prinsip dasar dari model blended learning adalah mengoptimalkan pengintegrasian komunikasi lisan yang ada pada pembelajaran tatap muka dengan komunikasi tertulis pada pembelajaran online. Blended learning merupakan gabungan dari teknologi multimedia, video streaming, CD ROM kelas virtual, voicemail, email, telefon conference, animasi teks online dan video-streaming. Kesemuanya itu digabungkan dengan bentuk pembelajaran secara konvensional di dalam kelas. Blended learning dijadikan jalan keluar yang paling tepat untuk aktifitas pembelajaran yang sesuai pada zamannya dan tidak hanya dengan kebutuhan guru akan tetapi juga gaya belajar siswanya (Thorne, 2003: 16). Tujuan Blended learning (Husamah, 2014: 22) diantaranya dapat: (1) Membantu siswa untuk berkembang lebih baik di dalam proses belajar sesuai dengan 
gaya belajar dan preferensi dalam belajar; (2) Menyediakan peluang yang praktis-realistis bagi pengajar dan siswa untuk pembelajaran secara mandiri, bermanfaat, dan terus berkembang; (3) Peningkatan penjadwalan fleksibilitas bagi siswa dengan menggabungkan aspek terbaik dari tatap muka dan pembelajaran online, sedangkan komponen dalam blended learning yaitu: (1) Face-to-face Learning, (2) E-learning Offline, (3) E-learning Online, (4) Mobile Learning.

\section{METODE PENELITIAN}

Penelitian ini bertujuan untuk melihat kemampuan representasi simbolik matematik siswa dan respon siswa pada pembelajaran matematika menggunakan blended learning sehingga menggunakan metode penelitian deskriptif dengan pendekatan kuantitatif. Pendekatan ini digunakan apabila tujuan untuk mendeskripsikan atau menjelaskan peristiwa atau suatau kejadian yang terjadi pada saat sekarang dalam bentuk angka-angka yang bermakna (Sudjana dan Ibrahim, 1989). Subjek terdiri dari 30 siswa Sekolah Menengah Pertama Negeri 3 Cianjur Kelas IX-6 tahun ajaran 2019/ 2020. Alasan untuk memilih sekolah tersebut dikarenakan peneliti melaksankan PDS (Penugasan Dosen di Sekolah) tahun 2019.

Untuk mengetahui kemampuan representasi simbolik siswa, diberikan tes yang terdiri dari 6 soal uraian pada materi Eksponen yang dirancang berdasarkan indikator kemampuan representasi simbolik matematik. Suatu kelas disebut tuntas belajarnya jika 85\% siswa dalam kelas tersebut telah mencapai nilai KKM mata pelajaran matematika yang ditentukan oleh sekolah tersebut yaitu 70.

Angket digunkan untuk melihat respon siswa terhadap pembelajaran matematika menggunakan blended learning, dalam bentuk google form dengan empat pilihan jawaban mengacu pada skala likert, yaitu kurang baik, cukup baik, baik dan sangat baik dengan skor 1, 2, 3, dan 4 dengna menggunakan penyataan positif sebanyak 20 pernyataan. Kategori persentase hasil angket yang digunakan menurut Koentjaningrat, yaitu: 0\% (tidak ada yang positif), $1 \%$ - 25\% (sebagian kecil positif), 26\% - 49\% (hampir setengahnya positif), 50\% (setengahnya positif), 51\% - 75\% (sebagian besar positif), 76\% - 99\% (pada umumnya positif), dan $100 \%$ (seluruhnya positif).

\section{HASIL DAN PEMBAHASAN}

Pada pelaksanaan pembelajaran, peneliti malaksanakan sesuai perangkat Rencana Pelaksanaan Pembelajaran yang mengacu pada pelasanaan blended lerning, yang pada 
pelasanaannya terdiri dari: 1) face-to face learning; 2) e-learning offline (pengunaan power point oleh guru; 3) mobile learning (gabungan face-to-face dengan e-learning), siswa mengintegrasikan aplikasi you tube serta google dalam pembelajaran di kelas.

Berdasarkan hasil skor tes kemampuan representasi simbolik matematik pada materi eksponen yang diperoleh setelah pembelajaran menggunakan blended learning disajikan pada Tabel 1.

Tabel 1. Representasi Simbolis Matematis Siswa

\begin{tabular}{lccc}
\hline \multicolumn{1}{c}{ Indikator Soal } & \multicolumn{2}{c}{ No } & \multicolumn{2}{c}{ \% Siswa Menjawab Soal } \\
& Soal & Benar & Salah \\
\hline $\begin{array}{l}\text { Siswa dapat merepresentasikan konsep operasi pangkat ke } \\
\text { dalam bentuk symbol }\end{array}$ & 2 & 60 & 40 \\
& 3 & 67 & 13 \\
Siswa dapat merepresentasikan konsep operasi bentuk akar ke & 4 & 67 & 13 \\
$\begin{array}{l}\text { dalam bentuk symbol } \\
\text { Siswa dapat merepresentasikan soal pada konteks nyata ke }\end{array}$ & 5 & 83 & 50 \\
bentuk baku / ke bentuk symbol & 6 & 83 & 17 \\
\hline
\end{tabular}

Tabel 2. Ketuntasan Belajar Siswa

\begin{tabular}{ll}
\hline \multicolumn{1}{c}{ Siklus } & \multicolumn{1}{c}{ II } \\
\hline Ketuntasan Belajar (\%) & $83,3 \%$ \\
Rata-Rata Skor Tes & 75 \\
Tuntas & 25 siswa \\
Tidak tuntas & 5 siswa \\
Maksimum & 100 \\
Minimum & 40 \\
\hline
\end{tabular}

Kemampuan representasi simbolik matematis siswa yang disajikan dalam Tabel 2 memperlihatkan bahwa dengan menggunakan blended learning menyebabkan kelas tersebut telah tuntas belajarnya karena telah mencapai $83,3 \%$ siswa mencapai $\geq \mathrm{KKM}$ sekolah yaitu 70. Dari data angket siswa bahwa sebanyak 21 siswa dengan persentase sebesar $70 \%$ memberikan respon positif pada pembelajaran matematika menggunakan blended learning dan 9 siswa yakni $30 \%$ memberikan respon yang negatif.

Tabel 3. Data Hasil Angket Siswa

\begin{tabular}{cccc}
\hline No & Sifat Pernyataan & Jumlah Siswa & $\%$ \\
\hline 1. & Positif & 21 & 70 \\
2. & Negatif & 9 & 30 \\
\hline
\end{tabular}

Berdasarkan data pada Tabel 3, terdapat dua sifat pernyataan, yaitu positif dan negatif. Meskipun masih ada siswa yang memberikan respon negatif tetapi sebagian besar siswa memberikan respon yang positif. Dengan penggunaan blended learning pada pembelajaran matematika yang dilakukan guru dapat meningkatkan keefektifan belajar 
siswa, menjadikan pembelajaran lebih menyenangkan dan tingkat kreatif siswa bisa terlihat pada saat pembelajaran yang mengakibatkan kemampuan representasi simbolik siswa menjadi baik pula. Meskipun blended learning pada faktanya menerapkan gabungan dari pembelajaran tatap muka, e-learning offline, e-learning online akan tetapi dalam implementasinya tetap menyeseuaikan dengan sarana dan prasarana yang ada di sekolah, sehingga siswa antusias dan lebih merespon instruksi yang diberikan guru pada saat pembelajran karena mereka bisa memanfaatkan teknologi yang ada secara online, misalnya dengan nonton video pembelajaran di youtube yang sesuai dengan materi pada pertemuan tersebut dan juga bisa memanfaatkan Google untuk membantu menyelesaikan latihan soal. Selain itu bahan-bahan online juga oleh siswa dapat di manfaatkan tanpa harus mewajibkan siswa untuk dapat terhubung dengan internet sebagai pendukung pembelajaran, hal tersebut juga merupakan salah satu bentuk sederhana dari implementasi blended learning. Sejalan dengan pendapat Kusairi (Husamah, 2014: 216), model implementasi yang paling sederhana yaitu dengan memanfaatkan bahan-bahan online tanpa mengharuskan siswa untuk terhubung dengan internet. Selain itu terbentur dengan aturan sekolah yang tidak memperbolehkan siswanya membawa HP (alat komunikasi), salah satu solusi yang dilakukan peneliti adalah adanya kerjasama siswa dengan guru matematika sebelum dan setelah pembelajaran yakni dengan mengelola alat komunikasi tersebut, selain itu penggunaan bahan-bahan online secara berkelompok, serta penggunaan bahan-bahan online yang disajikan langsung di depan kelas oleh peneliti yang bias dimanfaatkan secara bersama-sama.

Berdasarkan temuan dilapangan adanya keterbatasan siswa atas kepemilikan gadget, keterbatasan kuota dan jaringan internet sekolah yang disediakan terbatas. Dari hal tersebut, mengharuskan kita sebagai pengajar menjadi lebih kretif dalam pelaksanaan blanded lerning. Dengan begitu blended learning, selain memiliki kelebihan pasti ada kekurangan yaitu: 1) Media yang dibutuhkan sangat bervariasi, sehingga sukar diterapkan jika tidak didukung dengan sarana dan prasarana; 2) Fasilitas yang dimiliki siswa tidak merata (komputer dan akses internet); 3) Pengetahuan sumber daya pembelajaran (siswa, guru, dan orang tua) terhadap penggunaan teknologi masih kurang (Noer dalam Husamah, 2014: 36). Kusni (Husamah, 2014: 37) juga menyatakan bahwa blended learning menyebabkan berbagai masalah terutama bagi guru, antara lain: (1) Guru perlu memiliki keterampilan dalam menyelenggarakan e-learning; (2) Guru perlu menyiapkan referensi digital yang dapat menjadi acuan bagi siswa; (3) Guru perlu merancang referensi yang sesuai atau terintegrasi dengan tatap muka; (4) Guru perlu menyiapkan waktu untuk 
mengelola pembelajaran berbasis internet, misalnya untuk mengembangkan materi, mengembangkan instrumen asesmen, dan menjawab berbagai pertanyaan yang diajukan oleh siswa.

Namun aktifitas pembelajaran tidak hanya berdasarkan pada penggunaan teknologi saja, karena pada hakikatnya pembelajaran lebih pada proses interaksi antara guru, siswa dan sumber belajar. Sekalipun e-learning dapat digunakan siswa secara individu, namun keberadaan guru menjadi sangat penting dan berarti sebagai orang dewasa yang berperan sebagai pemberi dukungan dan mendampingi siswa dalam proses pembelajaran Plummer (Danim 2012: 1). Dengan demikian proses tatap muka (pembelajaran secara konvensional) menjadi hal yang penting dan tidak bisa ditinggalkan dalam pembelajaran, sehingga suatu model pembelajaran akan menjadi lebih bermakan bagi siswa ketika aktifitas pembelajaran didalamnya secara sistematis dapat menggabungkan metode tatap muka dengan $e$-learning.

\section{KESIMPULAN}

Kemampuan representasi simbolik matematik dengan menggunakan blended learning, hasil pembelajarannya tuntas. Respon siswa terhadap pembelajaran matematika menggunakan blended learning sebagian besar memberikan respon positif.

\section{REFERENSI}

Danim, Sudarwan. (2012). Pengembangan Profesi Guru: dari Pra-jabatan, Induksi, Keprofesional Madain. Cetakan kedua. Jakarta: Kencana.

Garrison, D. R., a Vaughan, N. (2008). Blended Learning in Higher Education. San Francisco: Jossey-Bass.

Husamah. (2014). Pembelajaran Bauran (Blended Learning). Jakarta: Prestasi Pustaka Jaya.

Komala, E dan Suryadi, D. (2018). Analysis of internal and external mathematical representation ability to senior high school students in Indonesia. IOP Conf. Series: Journal of Physics: Conf. Series 1132 (2018) 012047.

Komala, E,. Suryadi, D dan Dasari, D. (2020). Learning Obstacle Related to the Ability of High School Student Representation to the Trigonometry Concept. Proceeding books: The 2nd International Conference and Innovation Exhibition Global Education (ICEGE). 17-18 Januari, 43-49.

Maskur, R., Sumarno, Rahmawati, Y., Pradana, K., Syazali, M., Septian, A., \& Palupi, E. K. (2020). The effectiveness of problem based learning and aptitude treatment interaction in improving mathematical creative thinking skills on curriculum 2013. European Journal of Educational Research, 9(1), 375-383. https://doi.org/10.12973/eu-jer.9.1.375NCTM. (2000). Principles and Standards for School Mathematics. Reston: The National Council of Teachers of Mathematics, Inc.

Sanusi, A. M., Septian, A., \& Inayah, S. (2020). Kemampuan Berpikir Kreatif Matematis dengan Menggunakan Education Game Berbantuan Android pada Barisan dan Deret. Mosharafa: Jurnal Pendidikan Matematika, 9(September), 511-520.

Septian, A., Darhim, \& Prabawanto, S. (2020). Geogebra in integral areas to improve 
mathematical representation ability. Journal of Physics: Conference Series, 1613(1), 12035. https://doi.org/10.1088/1742-6596/1613/1/012035

Septian, A., Darhim, \& Prabawanto, S. (2020). Mathematical representation ability through geogebra-assisted project- based learning models. Journal of Physics: Conference Series, 1657(1), 12019. https://doi.org/10.1088/1742-6596/1657/1/012019

Septian, A., Suwarman, R. F., Monariska, E., \& Sugiarni, R. (2020). Somatic , auditory , visualization, intellectually learning assisted by GeoGebra to improve student's mathematical representation skills. Journal Of Physics : Conference Series, 1657(1), 12023. https://doi.org/10.1088/1742-6596/1657/1/012023

Seidl, M. (2005). Blended Learning With Moodle: Didactical and Technical Aspects of Blended Learning Scenario with Moodle. $10^{a}$ Conferência Internacional Netties, Universidade de Ciências Aplicadas de St. Pölten, na Áustria.. International Journal of Education and Research, Volume 1, 1-12.

Sudjana, N dan Ibrahim. (1989). Penelitian dan Penilaian Pendidikan. Bandung: Sinar Baru.

Tall, D. (1996). A Versatile Theory of Visualisation and Symbolisation in Mathematics. Proceedings of the 46 th Conference of CIEAEM, 1(July),15-27.

Thorne, Kaye. (2003). How To Integrate Online and Traditional Learning. London: Kogan Page.

Tsany, U. N., Septian, A., \& Komala, E. (2020). The ability of understanding mathematical concept and self-regulated learning using macromedia flash professional 8. Journal Of Physics: Conference Series, 1657(1), 12074. https://doi.org/10.1088/1742-6596/1657/1/012074

Villegas, J.L., et al. (2009). Representations in Problem Solving: A Case Study in Optimization Problems. Electronic Journal of Research in Educational Psychology. No. 17, Vol. 7(1). 